\title{
EVALUATION OF THE SURFACE OF ROOT CANAL WALLS AFTER UTILIZATION OF ENDODONTIC ROTARY SYSTEMS: SEM STUDY
}

\author{
AVALIAÇÃO SUPERFICIAL DAS PAREDES DE CANAIS APÓS O USO SISTEMAS \\ DE INSTRUMENTAÇÃO ROTATÓRIA: ESTUDO EM MEV
}

José Carlos YAMASHITA ${ }^{1}$, Marco Antonio Hungaro DUARTE ${ }^{1}$, Fernanda Araújo VALIM ${ }^{2}$, Juliano Milanezi de ALMEIDA², Milton Carlos KUGA ${ }^{3}$, Sylvio de Campos FRAGA ${ }^{3}$

1- DDS, PhD, Assistant Professor, Department of Endodontics, University of Sagrado Coração.
2- DDS, Graduate Student, Department of Endodontics, University of Sagrado Coração.
3- DDS, PhD, Associate Professor, Department of Endodontics, University of Sagrado Coração.

Corresponding address: José Carlos Yamashita - R. Anesia Pinheiro Machado, 2-40 - Cep.: 17045-360 - Bauru, SP, Brazil

telephone (14) 3224-3107 - E-mail: rezeyama@usp.br

Received: August 17, 2004 - Modification: September 28, 2004 - Accepted: October 5, 2004

\begin{abstract}
$T$ he objective of the present study was to determine, by scanning electron microscopy, the aspect of root canal walls after utilization of different rotary instrumentation systems for root canal preparation. Forty-two single-rooted and straight teeth were divided into six groups, whose root canals were prepared using the following rotary systems: groups 1 and 2 - Quantec; groups 3 and 4 - Pow-R; groups 5 and 6 - Profile. Irrigation was performed with 2.5\% sodium hypochlorite solution in all groups, while only groups 2, 4 and 6 received a final flush with EDTA. Data were analyzed by non-parametric Kruskal-Wallis and Miller tests. Removal of the smear layer and other debris was more effective in the groups receiving EDTA as final irrigant. The Profile system showed the best cleaning, generating only a minimum smear layer, with a significant difference being observed compared to the Pow-R system $(\mathrm{p}<0.05)$, but no difference when compared with Quantec system. The final use of EDTA favored cleaner surfaces in all groups.

Uniterms: Root canal preparation; Rotary instruments; Smear layer.
\end{abstract}

\section{RESUMO}

objetivo do presente estudo foi avaliar por meio de microscopia eletrônica de varredura, o aspecto superficial de paredes de canais radiculares apos uso de sistemas rotatórios de instrumentação endodôntica. Quarenta e dois dentes unirradiculados e com canais retilíneos foram divididos em seis grupos experimentais. Foram preparados utilizando-se os seguintes sistemas: Grupos 1 e 2 - Sistema Quantec; grupos 3 e 4 - Sistema Pow-R; grupos 5 e 6 - Sistema Profile. A irrigação foi realizada com solução de hipoclorito de sódio a 2.5\% em todos os grupos durante a instrumentação. Apenas nos grupos 2, 4 e 6 foi realizada toalete final dos canais com solução de EDTA. O dados foram analisados pelos testes não paramétricos de Kruskal-Wallis e Miller. Foi observada maior remoção de smear layer e outros resíduos nos grupos onde foi realizada a toalete final com solução de EDTA. O sistema Profile mostrou melhor resultado, gerando menor quantidade de resíduos, com diferença significante quando comparado com o sistema Pow-R(p<0.05), Mas não houve diferença quando comparado ao sistema Quantec. O uso de irrigação final com solução de EDTA favoreceu uma superfície mais limpa com todos os sistemas de instrumentação.

Unitermos: Preparo do canal radicular; Instrumentos rotatórios; Camada de esfregaço.

\section{INTRODUCTION}

According to Leonardo and $\mathrm{Leal}^{9}$ (1998), root canal preparation consists of obtaining a direct and clear access close to the cementum-dentin canal (CDR limit), followed by preparation of the dentinal canal by means of chemical/ mechanical cleaning and, at the same time, assigning a conic conformation in order to achieve easy and perfect obturation.

The development of new devices, instruments (Walia, et al. ${ }^{17}$ 1988), materials and techniques (Holland, et al. ${ }^{7}$ 1991) for 
root canal instrumentation is intended to reduce surgical inconveniences, maintain the real instrumentation length, reduce physical stress for the professional, simplify the difficult task of preparing a root canal throughout its extension, and support its simultaneous conic enlargement and cleaning.

Because of their high flexibility and resistance (Serene, et al. ${ }^{14}$ 1995), nickel-titanium instruments available on the market have simplified and facilitated the work of the professional by preparing an adequate morphological configuration of the root canals, i.e. a conic conformation and a well-defined apical stop without the risk of causing steps, zips, ledges or trephining, in addition to favoring their cleaning (Serene, et al. ${ }^{14}$ 1995). This new metal alloy has allowed the development of instruments operated with a continuous rotary motion. The use of completely automatized instrumentation would greatly facilitate endodontic procedures. However, since these technologies appeared relatively recently in the market, several doubts remain regarding the performance and safety of this type of instrumentation. Some studies (Bryant, et al. ${ }^{2,3}$ 1998a 1998b, Thompson and Dummer ${ }^{15,16}$ 1998a 1998b) in the literature refer to the maintenance of the original trajectory of the canal and deviations caused by these different techniques; however, few data are available regarding the surface cleaning ability of these techniques.

The aim of the present study was to evaluate in vitro the dentinal wall cleaning ability of three instrumentation systems operated with a continuous rotary motor (Quantec ${ }^{\circledR}$ system, Profile ${ }^{\circledR}$ system, Pow-R ${ }^{\circledR}$ system) by scanning electron microscopy (SEM), with the same irrigation solution being used for all experimental groups.

\section{MATERIALAND METHODS}

The present study was conducted on 42 human mandibular single-rooted, straight incisors, obtained from the tooth bank of the Endodontics Division of University of Sagrado Coração. The crowns were sectioned at the enameldentin junction with a diamond disc in order to eliminate the possibility of cervical interferences during biomechanical preparation. Roots with an extension of less than $10 \mathrm{~mm}$ were discarded. The canal was explored with a \#10 K type file until the end of the file was visible through the apical foramen, thus determining the length of the root. The extension of instrumentation was established by subtracting $1 \mathrm{~mm}$ from this measurement. The roots were analyzed with respect to two factors: factor A - type of instrumentation system (Quantec, Profile and Pow-R); factor B - presence or absence of the final irrigating agent (EDTA solution).

Combining the levels of the two factors, six groups with seven specimens were obtained as follows:

group 1 - Quantec system without a final flush; group 2 - Quantec system and a final flush with EDTA; group 3 - Pow-R system without a final flush; group 4 - Pow-R system and a final flush with EDTA; group 5 - Profile system without a final flush; group 6 - Profile system and a final flush with EDTA. The rotary systems used were the Quantec system
(Analytic Endodontics, Glendora, USA), Pow-R system (.02/ .04) (Moyco Union Broach - USA) and Profile system (.04/ .06) (Dentsply/Maillefer - Switzerland) according to the manufacturer's instructions with respect to the operative sequence of instrument use. All groups were submitted to cervical preparation with the respective instruments as recommended by the manufacturer, with the Flare series being used for the Quantec system, Orifice Shapers for the Profile system, and Coronal Shapers for the Pow-R system. Apical preparation was completed when the the canals were enlarged with the instrument equivalent to a $\# 40\left(D_{1}=0.40 \mathrm{~mm}\right)$. At each instrument change, the canal was irrigated with $2 \mathrm{ml}$ of a $2.5 \%$ sodium hypochlorite solution for all groups using a $5 \mathrm{ml}$ LuerLock syringe and a 30 x 5 cannula, which was inserted into the root canal up to approximately $3 \mathrm{~mm}$ of the working length. The canals of groups 1, 3 and 5 were then irrigated with $6 \mathrm{ml}$ of distilled water. For groups 2, 4 and 6, the canal was flushed with EDTA solution, which was shaken with a \#40 K type file for 3 minutes, and then irrigated with $6 \mathrm{ml}$ of distilled water.

After root canal preparation, they were dried by aspiration and absorbent paper points. The roots were then cleaved as follows: grooves were made on the buccal and lingual sides with 3203 diamond tips at high-speed and under abundant cooling without reaching the root canal, and the roots were longitudinally sectioned into two halves using a surgical chisel and a hammer. The halves were fixed in modified Karnovsky's solution for at least 48 hours. The specimens were then dehydrated in a solution of increasing acetone concentrations, dried to the critical point and sputtered with a gold alloy.

SEM images were obtained from the middle and apical thirds at 500x magnification, choosing the most representative regions of each half. The images were evaluated by two calibrated examiners who were unaware of to which experimental groups the photomicrographs belonged, and scored from 0 to 3, i.e. good to poor cleaning (Figure 1) (Garberoglio and Becce $^{6}$ 1994) as follows:

score 0: surfaces completely free of a smear layer, with the dentinal tubules completely exposed;

score 1: smear layer present in the opening of the dentinal

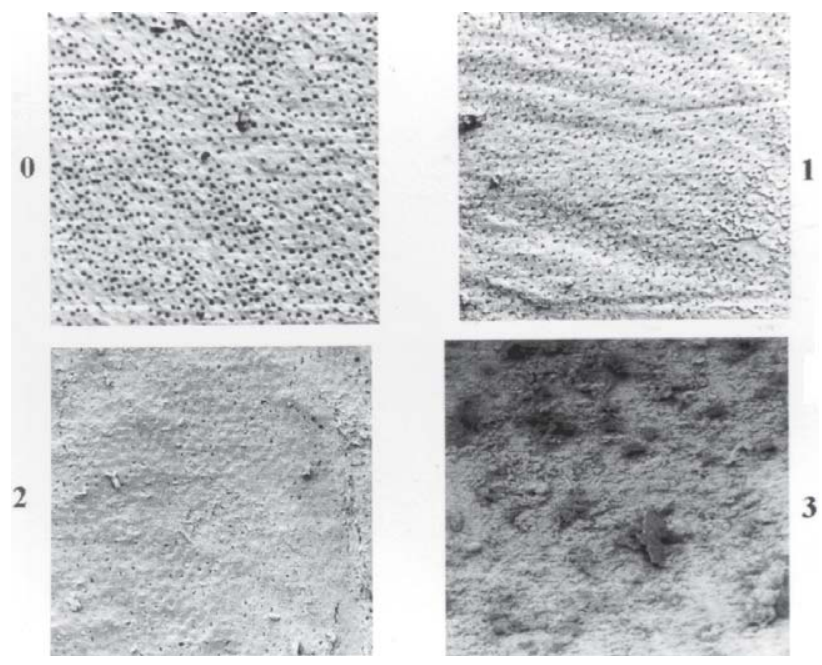

FIGURE 1- Scores used for scanning electron microscopy analysis (500x magnification) 
tubules;

score 2: a fine smear layer is covering the surface and the opening of the dentinal tubules is visible as a fissure;

score 3: surfaces are completely covered with debris.

Since scores were attributed to the two halves of each root, the mean of these two halves was considered for the scoring of each specimen.

The results were submitted to non-parametric statistical tests for comparison between groups using the Kruskal-Wallis test and for individual comparisons between groups using the Miller test.

\section{RESULTS}

Analysis and classification of the SEM images revealed the results listed below.

The mean scores attributed to the cervical and apical thirds are shown in Table 1 . Table 2 shows the individual comparisons between groups in the cervical third using the Miller test. A statistically significant difference was observed between groups 1 and 6, 3 and 6, and 5 and 6, with the lowest mean observed for group 6 (Profile system with EDTA).

Comparisons between the experimental groups with respect to the apical third using the Miller test are shown in Table 3. Again, a better cleaning ability was observed for the Profile system with a final EDTA flush (group 6) compared to the other groups, with a statistically significant difference being observed between group 6 and groups 1 and 3 .

When the use of EDTA was considered irrespective of the group, a significant improvement was observed in the cervical third, while in the apical third no significant difference was observed despite the fact that the use of EDTA improved cleaning.

Global analysis of the systems employed showed a better performance for the Profile system regardless of the use of EDTA, with observation of a significant difference between this system and the Pow-R system. When comparing Profile system with Quantec system, there was no statistical difference between groups.

\section{DISCUSSION}

The objective of instrumentation and irrigation is to promote cleaning and shaping of the root canals. These objectives can be achieved by mechanical, physical and chemical means, which are used in combination during endodontic preparation in order to yield the desired results, while separate use does not lead to success. Therefore, varying results can be obtained according to the combination of irrigation regimens and instrumentation systems used.

In the present study, the use of different rotary instrumentation systems led to different levels of cleaning

TABLE 1- Scores attributed to the apical (A) and cervical (C) third

\begin{tabular}{|c|c|c|c|c|c|c|c|c|c|c|c|c|}
\hline & \multicolumn{2}{|c|}{$\begin{array}{l}\text { Quantec } \\
\text { Without } \\
\text { EDTA(G1) }\end{array}$} & \multicolumn{2}{|c|}{$\begin{array}{l}\text { Quantec } \\
\text { With } \\
\text { EDTA(G2) }\end{array}$} & \multicolumn{2}{|c|}{$\begin{array}{l}\text { Pow-R } \\
\text { Without } \\
\text { EDTA(G3) }\end{array}$} & \multicolumn{2}{|c|}{$\begin{array}{l}\text { Pow-R } \\
\text { With } \\
\text { EDTA (G4) }\end{array}$} & \multicolumn{2}{|c|}{$\begin{array}{l}\text { Profile } \\
\text { Without } \\
\text { EDTA(G5) }\end{array}$} & \multicolumn{2}{|c|}{$\begin{array}{l}\text { Profile } \\
\text { With } \\
\text { EDTA(G6) }\end{array}$} \\
\hline & $A$ & C & A & C & A & C & $A$ & C & $A$ & C & $A$ & C \\
\hline 1 & 3 & 2 & 2 & 1 & 3 & 2.5 & 2.5 & 2 & 2.5 & 2.5 & 1 & 1 \\
\hline 2 & 3 & 2 & 2.5 & 1.5 & 3 & 3 & 2.5 & 1.5 & 2.5 & 2.5 & 1.5 & 1 \\
\hline 3 & 3 & 3 & 1 & 1 & 3 & 3 & 2 & 2 & 3 & 2.5 & 1 & 1 \\
\hline 4 & 3 & 2 & 1.5 & 1.5 & 3 & 3 & 2 & 2 & 2.5 & 2 & 1.5 & 0.5 \\
\hline 5 & 3 & 2.5 & 2.5 & 1.5 & 3 & 3 & 2.5 & 1 & 2.5 & 2.5 & 2 & 2 \\
\hline 6 & 2.5 & 2.5 & 2 & 1 & 3 & 3 & 2.5 & 1.5 & 2 & 2 & 2 & 1 \\
\hline 7 & 3 & 2.5 & 3 & 1 & 2 & 3 & 1.5 & 1.5 & 3 & 2.5 & 1 & 0 \\
\hline
\end{tabular}

TABLE 2- Results of the statistical analysis performed on the cervical group using the Miller test

\begin{tabular}{|c|c|c|c|c|c|}
\hline Groups & 2 & 3 & 4 & 5 & 6 \\
\hline 1 & 17.29 & 8.78 & 11.86 & 0.23 & $20.93^{*}$ \\
\hline 2 & & 17.07 & 6.43 & 18.57 & 2.64 \\
\hline 3 & & & 10.54 & 8.50 & $29.66^{*}$ \\
\hline 4 & & & & 12.14 & 8.07 \\
\hline 5 & & & & & $20.21^{*}$ \\
\hline
\end{tabular}

TABLE 3- Results of the statistical analysis performed on the apical group using the Miller test

\begin{tabular}{lccccc}
\hline Groups & $\mathbf{2}$ & $\mathbf{3}$ & $\mathbf{4}$ & $\mathbf{5}$ & $\mathbf{6}$ \\
\hline 1 & 17 & 1.36 & 16.07 & 8.79 & $26.9^{*}$ \\
2 & & 14.36 & 14.07 & 8.21 & 9.9 \\
3 & & & 14.71 & 7.13 & $26.28^{*}$ \\
4 & & & 7.28 & 10.57 \\
5 & & & & 17.85 \\
\hline Critical Value = 18.68 & & \multirow{2}{*}{ NS = 5\% } & & * Significant
\end{tabular}


during root canal preparation, as evidenced by SEM. The Profile system showed the best cleaning ability, followed by the Quantec and Pow-R systems, irrespective of the use of EDTA, with the difference being statistically significant. The Profile system possesses a plane conformation (radial land), whose angle is neutral and therefore does not attack the canal wall. Because it is less aggressive, this system generates only minimal smear layer. Association of the Profile system with EDTA resulted in even better cleaning.

The Quantec system presents a slightly positive conformation, producing a greater cutting ability and thus generating more smear layer. The cutting angle of the Pow-R system also possess a positive conformation, leading to greater aggression on the canal wall and thus generating even more smear layer than that produced by the Quantec instrumentation system. Even in the presence of a final EDTA flush, the cleaning ability of this system is lower than that of the Profile and Quantec systems.

All groups showed poorer cleaning in the apical third than in the more cervical portion due to the higher amount of irrigating solution acting in the latter region, creating a greater flow and favoring the chemical action of the solution. The difficulty in cleaning the apical third has also been reported in other studies (Yamada, et al. ${ }^{18}$ 1983, Bertrand, et al. ${ }^{1} 1999$, Peters and Barbakow ${ }^{12}$ 2000).

Similar findings regarding the complementary effect of the chelating action of EDTA have been reported in the literature, with a final EDTA flush being necessary for manual (Mc Comb and Smith ${ }^{11}$ 1975, Yamada, et al. ${ }^{18} 1983$, Czonstkowsky, et al. ${ }^{5} 1990$, Sen, et al. ${ }^{13}$ 1995) or rotary instrumentation (Bertrand, et al. ${ }^{1}$ 1999). Irrigation with sodium hypochlorite solution alone did not provide an adequate smear layer-free surface.

Sodium hypochlorite solution has been widely employed in endodontic treatment and was therefore used in the present study as endodontic irrigant. Since it is known that a chelating action is necessary for adequate cleaning, EDTA was chosen for final flushing of the canal walls (Sen, et al. ${ }^{13}$ 1995), except for groups 2, 4 and 6. This trials were used to determine the superficial cleaning ability and ability of removal of debris of the rotatory motion and different designs of instruments. As shown in other studies (Yamada, et al. ${ }^{18}$ 1983, Bystron and Sundqvist ${ }^{4} 1985$, Sen, et al..$^{13}$ 1995), the use of EDTA as a final irrigant for biomechanical root canal preparation is an important cofactor for the success of endodontic treatment. In the present study, EDTA always led to better superficial cleaning compared to the groups without EDTA. This was also the case for the subdivisions comparing the apical and cervical thirds, with the apical region showing poorer cleaning probably due to a greater difficulty of action of the instruments and to a reduction in the flow of the irrigating agents used for root canal preparation. In general, higher mean scores were observed in the apical third, which in turn led to poor scores in all groups.

A review of the literature showed that most studies have evaluated the benefits of removing the smear layer (Koskinen, et al. ${ }^{8}$ 1980, Holland, et al. ${ }^{7}$ 1991, Mallmann, et al. ${ }^{10}$ 1996) and then analyzed the amount of debris left on the surface of the prepared root canal walls by SEM, thus determining the cleaning effectiveness of automated preparations (Bertrand, et al. ${ }^{1}$ 1999, Peters and Barbakow ${ }^{12}$ 2000).

\section{CONCLUSIONS}

Based on the present results, the following could be concluded:

1 - groups using EDTA as final irrigant showed cleaner surfaces after instrumentation;

2 - the Profile system showed the best cleaning ability, followed by the Quantec and Pow-R systems.

3 - better cleaning results were observed for the cervical third than for the apical third in all groups.

\section{ACKNOWLEDGEMENT}

The authors are grateful to PIBIc/CNPq for financial support and NAP/MEPA-ESALQ/USP for the SEM technical support.

\section{REFERENCES}

1- Bertrand MF, Pizzardini P, Muller M, Medioni E, Rocca JP. The removal of smear layer using the Quantec system. A study using the scanning electron microscope. Int Endod J 1999 May;32(3):217-24.

2- Bryant ST, Thompson SA, Al Omari MA, Dummer PMH. Shaping ability of Profile rotary nickel-titanium instruments with ISO sized tips in simulated root canals: Part1. Int Endod J 1998 Jul;31(4):27581; Apr;9(4):137-42

3- Bryant ST, Thompson SA, Al Omari MA, Dummer PMH. Shaping ability of Profile rotary nickel-titanium instruments with ISO sized tips in simulated root canals: Part2., Int Endod J 1998 Jul;31(4):2829

4- Byströn A., Sundqvist G. The antibacterial action of sodium hipochorite and EDTA in 60 cases of endodontic therapy. Int Endod J 1985 Jan;18(1):35-40.

5- Czonstkowsky M, Wilson EG, Holstein FA. The smear layer in endodontics. Dent Clin North Am 1990 Jan;34(1):13-25.

6- Garberoglio R, Becce C. Smear layer removal by root canal irrigants. A comparative scanning electron microscopic study. Oral Surg 1994 Sept;78(3):359-67.

7- Holland R, Souza V, Otoboni Filho JÁ, Nery MJ, Bernabé PFE, Mello W. Técnicas mistas de preparo do canal radicular. Rev Paul Odont 1991;13:17-23.

8- Koskinen KP, Meurman JH, Stenvall H. Appearance of chemically treated root canal walls in the scanning electron microscope. Scan J Dent Res 1980 Oct;88(5):397-405.

9- Leonardo MR, Leal JM. Endodontia: tratamento de canais radiculares. $3^{\text {rd }}$ ed. São Paulo, SP, Brazil: Panamericana; 1998.

10- Mallmann J, Felippe WT, Soares IJ. Smear layer - é necessário removê-lo? Rev Bras Odont 1996; 53:35-8. 
11- Mc Comb D, Smith DC. A preliminary electron microscope study of root canals after endodontic procedures. J Endod 1975 Jul;1(7):23842

12- Peters OA, Barbakow F. Effects of irrigation on debris and smear layer on canal walls prepared by two rotary techniques: a scanning electron microscopic. J Endod. 2000 Jan;26(1):6-10.

13- Sen BH, Wesselink PR, Turkun M. The smear layer: a phenomenon in root canal therapy. Int Endod J 1995 May;28(3):141-8.

14- Serene TP, Adams JD, Saxena A. Nickel-titanium instruments: applications in endodontics. Saint Louis : Ishiyaku Euro America; 1995.

15- Thompson SA, Dummer, PMH. Shaping ability of Quantec series 2000 rotary nickel-titanium instruments in simulated root canals. Part 1. Int Endod J 1998a July;31(4):259-67.

16- Thompson SA, Dummer PMH. Shaping ability of Quantec series 2000 rotary nickel-titanium instruments in simulated root canals. Part 2. Int Endod J 1998b July;31(4):268-74.

17- Walia H, Brantley, WA, Gerstein, H. An initial investigation of the bending and torsional properties of nitinol root canal root canal files. J Endod 1988 July;14(7):346-51.

18- Yamada RS, Armas A, Goldman M, Lin PS A scanning electron microscopic comparion of a high volume final flush with several irrigating solutions. Part 3 . J Endod 1983 Apr;9(4):137-42. 